\title{
The Effect of Institutional Factors on the Value of Corporate Diversification
}

\section{Citation}

Kuppuswamy, Venkat, George Serafeim, and Belen Villalonga. "The Effect of Institutional Factors on the Value of Corporate Diversification." Advances in Strategic Management 32 (2014). (This was Harvard Business School Working Paper, No. 13-022, August 2012.)

\section{Published Version}

http://www.emeraldinsight.com/doi/abs/10.1108/S0742-332220140000031000

\section{Permanent link}

http://nrs.harvard.edu/urn-3:HUL.InstRepos:9502860

\section{Terms of Use}

This article was downloaded from Harvard University's DASH repository, and is made available under the terms and conditions applicable to Open Access Policy Articles, as set forth at http:// nrs.harvard.edu/urn-3:HUL.InstRepos:dash.current.terms-of-use\#OAP

\section{Share Your Story}

The Harvard community has made this article openly available.

Please share how this access benefits you. Submit a story.

Accessibility 
H A R VAR D

\title{
The Effect of Institutional \\ Factors on the Value of Corporate Diversification
}

\author{
Venkat Kuppuswamy \\ George Serafeim \\ Belén Villalonga
}

\section{Working Paper}

13-022

August 10, 2012 


\title{
The Effect of Institutional Factors on the Value of Corporate Diversification
}

\author{
Venkat Kuppuswamy, George Serafeim, and Belén Villalonga*
}

Draft, August 10, 2012

\begin{abstract}
Using a large sample of diversified firms from 38 countries we investigate the influence of several national-level institutional factors or 'institutional voids' on the value of corporate diversification. Specifically, we explore whether the presence of frictions in a country's capital markets, labor markets, and product markets, affect the excess value of diversified firms. We find that the value of diversified firms relative to their single-segment peers is higher in countries with less efficient capital and labor markets, but find no evidence that product market efficiency affects the relative value of diversification. These results provide support for the theory of internal capital markets that argues that internal capital allocation would be relatively more beneficial in the presence of frictions in the external capital markets. In addition, the results show that diversification can be beneficial in the presence of frictions in the labor market.
\end{abstract}

\footnotetext{
* Venkat Kuppuswamy is an Assistant Professor of Strategy and Entrepreneurship at University of North Carolina at Chapel Hill, George Serafeim is an Assistant Professor of Business Administration at Harvard Business School and Belen Villalonga is a Professor of Finance at New York University. We are grateful to participants at the FMA Napa Valley conference 2012, and seminar participants at UNC and Georgetown University for many helpful comments. All errors are our own. Contact emails: Venkat Kuppuswamy: venkat@unc.edu; George Serafeim: gserafeim@hbs.edu; Belen Villalonga: bvillalonga@hbs.edu.
} 
The effect of corporate diversification on firm value has been a focus of significant scholarly inquiry and debate over the past two decades. Core to this debate has been the so-called diversification discount. The "diversification discount” refers to the empirical observation that diversified firms are on average undervalued relative to their single-segment peers (Lang and Stulz, 1994; Berger and Ofek, 1995). While initially seen as evidence of value destruction from corporate diversification, subsequent work (Campa and Kedia, 2002; Villalonga, 2004) has shown that the finding of an average discount in the United States can be attributed entirely to sample-selection biases, calling into question the interpretation of the discount as evidence of value destruction arising from diversification. Furthermore, the finding that the discount found using Compustat data disappears when corporate operations are classified into business units using more fine-grained data calls into question the mere existence of a discount in the United States (Villalonga, 2003). It is worth noting, however, that the focus of this debate has been on the average effect of diversification on firm value. Scholars on both sides of the debate have found significant variance across diversified firms in the discounts and premiums at which they trade relative to single-segment firms, yet the sources of this variance have received much less attention (Stein, 2003). Moreover, outside of the United States the evidence about the mere existence of a discount is mixed, and has been subject to much less scrutiny (Villalonga, 2003). The present study seeks to fill this gap by examining how the strength of a country's institutional environment affects the value added by corporate diversification.

Prior work examining corporate diversification in an international context has tended to choose sample countries with similar degrees of institutional development. In separate studies, 
Lins and Servaes (1999, 2002) explore the existence of a diversification discount in welldeveloped institutional environments as well as emerging markets. While these studies reveal the presence of a diversification discount in both well-developed and weak institutional contexts as well as the role that ownership structures may play, they shed less light on whether (and which) aspects of a country's institutional environment influence the value of diversification. Similarly, while studies have shown that conglomerates or business groups in emerging markets can add significant value to member firms leading to a valuation premium for diversified groups (Khanna and Palepu, 2000; Khanna and Rivkin, 2001), it remains to be seen which factors related to institutional development explain a significant portion of the cross-sectional variance regarding the value of diversification across the world. Doing so requires a representative sample of firms from different institutional environments as well as measures of institutional development on multiple dimensions.

One effort in this regard is the work of Fauver et al. (2003), who attempt to link a country's state of capital market development to the value of internal capital allocation, but fail to find an effect. However, this study is limited in several key respects. First, due to poor coverage of emerging markets during the sample period (between 1991-1995), their international sample consists primarily of firms from developed institutional contexts. As a result, the lack of a relationship between the efficiency of external capital markets and the value of corporate diversification may be due to insufficient variation in this institutional factor. Second, the study did not examine whether aspects of the institutional environment highlighted in prior theoretical work, such as the quality of the country's labor market and the efficiency of its product markets, 
do in fact influence the value of diversification (Khanna and Palepu, 2010). Third, as prior scholars have highlighted, endogeneity issues are a significant factor in any analysis of the value added by diversification (Villalonga, 2003). Consequently, the lack of self-selection models cast concern over their prior findings. Finally, since the primary explanatory variables regarding institutional efficiency vary only at the country-level, standard errors must be corrected by clustering at the country-level. Consequently, in light of the limitations of prior work in this domain, Stein (2003) notes that "taken together, the results from this effort thus far seem inconclusive.”

In this paper, we investigate whether and how the value of corporate diversification varies with institutional development. Namely, which institutional factors, if any, drive the observed differences in the value of diversification across firms and countries? To answer this question, we assemble a large data set consisting of diversified firms from 38 countries over the 15-year period from 1995 to 2009. We focus on several institutional variables that might affect the value of diversification, including the efficiency of a country’s capital markets, labor markets, and product markets. Specifically, we analyze whether these institutional variables explain the variance in the value of diversified firms across different countries, as well as within the same country over time.

Consistent with Stein’s (1997) internal capital markets theory, which suggests that the ability of diversified firms to fund and pursue projects by reallocating funds from other divisions is significantly more valuable in settings with frictions in the external capital market, we find that the value of diversified firms relative to their single-segment peers is indeed higher in countries 
with less efficient capital markets. In addition, we find evidence that the efficiency of the country's labor market also has a significant effect on the excess value of diversified firms. In countries where frictions in the labor markets are present, the value of diversified firms relative to their single-segment peers is greater. This finding supports Khanna and Palepu's (2010) argument that other institutional voids besides those that may exist in capital markets can also influence the value of corporate diversification. However, we find that the efficiency of a country's product market does not influence the relative value of diversified firms, after the state of the external capital markets and labor markets are accounted for. This finding suggests that frictions in the input factor markets, e.g. capital and labor, dominate frictions in the output factor market, as determinants of the value of diversification.

In addition to our cross-sectional analysis of the value of diversification, we estimate models with country fixed effects to examine whether changes in the institutional environment of a given country over time influence the relative value of its diversified firms. Consistent with Shleifer and Vishny (1991), Hubbard and Palia (1999), and Kuppuswamy and Villalonga (2011), we find evidence that as capital markets become more efficient, the value of corporate diversification decreases. Changes in other institutional factors within a country have no significant impact on the value of diversification. It is important to note, however, that these other factors exhibit little longitudinal variation within a given country, which makes difficult to identify their effect on the value of diversification using just changes within a country over time.

The rest of the paper proceeds as follows. Section I describes our predictions about the effect of institutional factors on the value of corporation diversification. Section II describes the 
sample and the data. Section III presents the results of our analysis of whether and which institutional factors explain the variation in the value of diversification around the world. Section IV presents some robustness checks. Section V analyzes within-country changes in the value of diversification. Section VI concludes.

\section{The Institutional Environment and the Value of Corporate Diversification}

The value of internal capital allocation and thus, corporate diversification, is likely to depend on a firm's institutional environment (Williamson, 1975). Specifically, the literature on internal capital markets has highlighted several potential benefits and costs to internal capital allocation, the net effect of which should vary with the institutional context. The main benefit of internal capital allocation is the ability of corporate headquarters to engage in "winner picking," whereby funds can be diverted away from one division to pursue more promising projects in another division that might be capital-constrained in more focused firms (Stein, 1997). Focused or stand-alone firms may face capital constraints regarding such projects due to imperfections in the external capital market arising from information asymmetries or a generalized shortage of credit offered by the external markets (Stein, 1997; Kuppuswamy and Villalonga, 2011).

However, internal capital markets also present a 'dark side', where the CEO or divisional managers may engage in rent-seeking behavior that leads to a misallocation of corporate resources (Rajan, Servaes, and Zingales, 2000; Scharfstein and Stein, 2000). In institutional contexts where external capital markets are inefficient and fraught with imperfections, the benefits of 'winner picking' become more significant and counter the costs of rent-seeking 
behavior to a greater extent. As a result, diversification is likely to be more valuable in countries with less efficient external capital markets (Khanna and Palepu, 2000).

Apart from the efficiency of external capital markets, prior work notes that the presence of other "institutional voids" may also increase the value of corporate diversification (Khanna and Palepu, 1999). In particular, frictions in a country’s labor market may substantially increase the transaction costs associated with operating a stand-alone business relative to a diversified operation (Williamson, 1975). Inefficiencies in the labor market may arise from a variety of sources including the limited supply of talent from professional or technical schools, the decreased ability of employees to leave their existing employer and move to another one, and undue governmental inference in wage negotiations between labor and business (Khanna and Palepu, 1999, 2010). Such frictions in the labor market can significantly increase the costs associated with searching for and securing the technical and managerial talent needed for a promising project. Internal labor markets operated by diversified firms in such environments can minimize these transaction costs. For example, diversified firms have the ability to source managerial talent from other existing divisions. Indeed, Tate and Yang (2012), who analyze the labor market consequences of corporate diversification within the United States, find that workers in diversified firms have greater cross-industry mobility within and across firms, and that diversified firms benefit from the opportunity to redeploy workers internally from declining to expanding industries. Moreover, the ability to expose internal talent to a diverse set of situations and business activities may enable diversified firms to develop internal talent and 
overcome limitations in educational infrastructure. As a result, corporate diversification may be more valuable in contexts with voids in their labor market institutions.

Another institutional void concerns the efficiency of a country’s product markets. Specifically, this refers to the extent to which a country’s regulatory and political context promotes fair and effective competition among firms in the product marketplace. Barriers to entry instituted by direct government intervention or excessive regulatory hurdles can lead to the lack of entry of intermediaries such as retailers, who are needed to facilitate the sale of goods and services to consumers (Khanna and Palepu 2010). Similarly, import tariffs and processing hurdles set up by customs authorities can limit the timely supply of necessary inputs to firms, restricting their ability to compete downstream. Moreover, regulatory roadblocks can impede the ability of firms to exploit new business opportunities that might emerge through the introduction of new products or services. Finally, direct government involvement, through state control of enterprises or subsidies to certain groups may further distort the ability to compete fairly in certain industries. Unlike stand-alone enterprises, divisions in diversified companies can overcome some of these obstacles by leveraging the experience and resources of other divisions within the company. For example, diversified firms may be able to overcome the lack of suitable intermediaries for the distribution and sale of its products from one business by deploying its distribution and retail assets from another. Furthermore, a diversified firm may be able to leverage its experience and relationships with regulatory authorities from one business to expedite the administrative process required to pursue new opportunities in another line of business. Diversified firms may also be able to exploit economies of scope through the sharing of 
common inputs between divisions (Penrose 1959). Consequently, they may be able to reduce the risk of a supply disruption, if the necessary raw materials are available from other divisions. As a result, diversification is likely to be more valuable in institutional environments characterized by inefficient product markets.

\section{Data and Variables}

\section{A. Sample}

Our sample consists of 10,164 diversified and 21,737 single-segment firms across the world that we draw from the Worldscope international database. ${ }^{1}$ Worldscope maintains financial and business segment data on publicly listed companies across the world. ${ }^{2}$ The aggregate market capitalization of companies in the Worldscope database stands at approximately 95\% of the total value of the world's markets (Thomson Financial, 2003). While the database targets publicly listed firms from 53 countries, its coverage of emerging markets is quite weak before 1995 (Lins and Servaes, 2002). Therefore our sample period begins in 1995, and ends in 2009. Worldscope records financial data regarding a firm’s 10 largest business segments, each of which is assigned a 4-digit SIC code to indicate its industry affiliation.

Following previous literature, we classify diversified firms as those with at least two segments with distinct 4-digit SIC codes (Berger and Ofek 1995; Villalonga 2004). Due to a

\footnotetext{
${ }^{1}$ Our primary sample is restricted to diversified firms. However, single-segment firms are used in the computation of the excess values of our diversified firms as well as in the first stage of the two-step Heckman selection models.

${ }^{2}$ For other studies that have used segment data from Worldscope for international firms see Lins and Servaes (1999), Ashbaugh and Pincus (2001), and Healy et al. (2011).
} 
significant degree of missing asset totals for individual segments, we focus on the sales figures of individual segments in constructing both our dependent variable as well as selecting firms into our sample. Following Berger and Ofek (1995), we restrict our sample of diversified firms to those firm-year observations where the segment totals are not subject to significant under or over-reporting. Specifically, we restrict our sample to those diversified firms for which the sum of segment sales was within 5\% of the firm's total sales in that year. Furthermore, we ensure that our sample firms had no segments with one-digit SIC codes of 0 (agriculture), 6 (financial), or 9 (government). In total, we have 35,886 firm-year observations from 10,164 diversified firms across 38 countries. Table I shows a breakdown of the number of observations per country. Firms from the United States, Japan, and United Kingdom represent 45\%, 18\%, and 11\% of the sample, with a substantial number of observations also coming from Australia, Canada, China, France, Germany, Hong Kong, India, Malaysia, Singapore, Sweden, Taiwan, and Thailand.

[Table I approximately here]

\section{B. Measures}

\section{Dependent Variable.}

The dependent variable of our study is Excess Value, a measure developed by Berger and Ofek (1995) that represents the value of a diversified firm relative to its single-segment peers. Excess values are computed as the natural logarithm of the ratio between a firm's market value and its imputed value at the end of the year. A firm's imputed value is the sum of its segments' imputed values, which are obtained by multiplying the segment's sales total by the median 
market-to-sales ratio of single-segment firms in the same industry, country, and year. The industry matching is carried out using the narrowest SIC grouping that includes at least five single-segment firms. Due to potential over or under-reporting of segment sales totals (within our $5 \%$ threshold), we gross up or down the imputed value by the percentage deviation in firm sales and segment sales totals. Furthermore, following prior literature on the diversification discount, we exclude outliers from our analysis. Specifically, we exclude observations with excess values that fall beyond the two standard deviations from the mean. Yet our results are very similar if we define outliers to be excess values that fall beyond the top $1 \%$ and bottom $1 \%$ of all excess values.

Table I shows mean and median excess values per country. As the table shows, there is considerable variation across countries in the value of diversified firms relative to single-segment firms, ranging from a discount of $75 \%$ for New Zealand to a premium of $62 \%$ for Russia. However, the countries at the tails of the distributions have very few observations. Leaving aside those countries with less than 20 observations, the range narrows down to an average discount of $46 \%$ for the Netherlands and a premium of 30\% for Poland - still a very wide range.

While our dependent variable measures the value of a diversified firm relative to its single segment peers, one potential source of bias in this measure is the fact that certain singlesegment firms may actually be members of business groups and thus have access to the capital resources of other firms (Khanna and Palepu 2000). The lack of widespread data on business group affiliations precludes us from accounting for such single-segment firms. Nevertheless, to the extent that certain single-segment comparables may actually have access to the internal 
capital markets possessed by diversified firms, this should actually bias us away from finding an effect regarding the relative benefits of diversification in contexts with weaker institutions. As a result, our results would represent a conservative estimate on the relative value of diversification in such contexts.

\section{Independent Variables.}

The core independent variables in our analysis are measures of several key facets of a country's institutional environment—-the efficiency of its capital, labor, and product markets. Annual data on the institutional variables are derived from the IMD World Competitiveness

Yearbook (WCY). Since 1996, IMD has analyzed and ranked the ability of nations to create and maintain an environment that sustains enterprise competitiveness. The yearbook compares the performance of 58 countries based on more than 300 criteria measuring different facets of competitiveness. Approximately two thirds of the data come from statistical databases (international/national sources) and the remaining third from surveys (Executive Opinion Survey). The statistical indicators provided by WCY are acquired from international, national and regional organizations, private institutions and a network of 54 partner institutes worldwide. The Executive Opinion Survey measures perceptions of competitiveness by business executives who are dealing with international business situations. They cover factors that are not easily measurable using output data, such as management practices, labor relations, corruption, environmental concerns, and quality of life. 
The measures of capital market efficiency, labor market efficiency, and product market efficiency are logarithms of reversed ordinal country rankings derived from pertinent WCY survey items which are outlined in Table III. The Capital Market Efficiency variable includes measures of the efficiency of banks, stock markets, and other types of financial intermediaries. ${ }^{3}$ The Product Market Efficiency variable includes measures that reflect both the openness of the product markets to foreign firms, and policies, laws and regulations that directly affect the level of competition in the product market. Labor Market Efficiency includes measures of the rigidity of the labor market and policies and laws that affect the supply of labor. To construct each of these variables, the institute first standardizes each of the WCY data items reported in the appendix in a given year by subtracting its mean and dividing by its cross-country standard deviation. This effectively forces each item to have equal importance. The institute then calculates the mean of the standardized survey items to generate an aggregate measure of capital, labor, and product market efficiency. For each of our institutional variables, the sample countries are assigned an ordinal ranking reflecting their relative performance. Finally, we reverse and take the logarithm of the ordinal rankings so that higher values of our institutional variables reflect contexts with higher efficiency.

Summary statistics and pairwise correlations for the main variables are presented in Table II. Excess Value exhibits a negative univariate correlation with all institutional variables. As expected, all institutional variables exhibit a strong positive correlation (0.36-0.68). However, as

\footnotetext{
${ }^{3}$ Apart from a country's capital markets, firms could also access capital from foreign sources through Foreign Direct Investment. In unreported analyses, our results are robust to the inclusion of a control variable measuring FDI inflows as a percentage of GDP in all our models.
} 
we will highlight later in the results section, variance inflation factors computed at the end of each analysis indicate that multicollinearity is not a concern in the analysis (Kutner et al., 2004).

[Table II approximately here]

\section{Control Variables.}

In addition to the institutional variables that are the focus of our analysis, we include several control variables in all of our models. Specifically, we include the following firm characteristics: log of total assets, the ratio of cash and marketable securities to the book value of assets, leverage, dividends paid as a percentage of equity, return on assets, and the ratio of capital expenditures to total assets. We also control for the country's economic performance to make sure that our institutional development measures are not merely capturing the country's economic development. ${ }^{4}$ In analogous fashion to the institutional measures of our interest, a country's economic performance is measured by the logarithm of its reverse WCY rank on that dimension, which takes into account the size, past and forecasted growth, and wealth of the domestic economy, the state of international trade, and international investments.

\section{How Do Institutional Factors Affect the Value of Corporate Diversification Across the World?}

A. Multivariate OLS Regressions

4 For more information about this measure, see the IMD competitiveness report: http://www.imd.org/research/publications/wcy/upload/ep_list.pdf. 
To examine the effect of our institutional variables on the relative value of diversified firms, we first run an Ordinary Least Squares (OLS) model with Excess Value regressed as a function of Capital Market Efficiency, Labor Market Efficiency, Product Market Efficiency, and our control variables. The results are shown in Table III. Models (1) through (3) include only one of our institutional variables, while Model (4) includes all of them simultaneously as covariates. We note that, while our institutional variables are correlated with one another to a significant degree (see Table II), multicollinearity does not appear to be a concern in including them together in Model (4): The variance inflation factors computed for each of our covariates is less than 3.5, which is well below the typical threshold of 10 used to signal multicollinearity concerns (Kutner et al. 2004). All models include year fixed effects, and standard errors that are clustered by country and robust to heteroscedasticity.

[Table III approximately here]

The results of Models (1) - (3) indicate that when included on their own, Capital Market Efficiency, Labor Market Efficiency, and Product Market Efficiency each have negative coefficients that are significant at the $1 \%$ level. ${ }^{5}$ In other words, in contexts where capital, labor, or product markets are more efficient, the value of diversified firms relative to their singlesegment peers decreases, as expected. In Model (4), where all our institutional variables are included at the same time. Capital Market Efficiency and Labor Market Efficiency continue to

\footnotetext{
${ }^{5}$ In addition, we see in all models that ROA has a negative and highly significant coefficient. This counter-intuitive result is driven by the presence of small firms that have high growth opportunities but poor profitability. If we were to restrict our sample to those firms with annual sales above $\$ 15$ million, the coefficient on ROA would be positive and highly significant.
} 
load negatively and significantly. However, after controlling for these other institutional factors, the coefficient of Product Market Efficiency turns statistically insignificant. If a country improves its capital market efficiency rank from $55^{\text {th }}$ in the world to $20^{\text {th }}$, the value of diversified firms relative to single-segment firms decreases by approximately 13\% (based on the coefficient in Model (4)). Similarly, if a country improves its labor market efficiency rank from $40^{\text {th }}$ in the world to $20^{\text {th }}$, the relative value of a diversified firm decreases by $6.5 \%$.

Collectively, the results from Model (4) provide evidence that institutional factors have a significant effect on the value of corporate diversification around the world. First, in support of the theory of internal capital markets, we find that the value of internal allocation and thus, the value of diversified firms relative to their single-segment peers is greater in contexts with less efficient capital markets (Stein, 1997, 2003). Moreover, we find evidence that the presence of frictions in a country's labor market also influences the value of corporate diversification. Consistent with the theory of institutional 'voids' in emerging markets, we find that in institutional environments where labor markets are less efficient, the relative value of diversified firms is higher (Khanna and Palepu, 2010). While we find strong evidence that both capital and labor market efficiency influence the value of diversification across the world, there is little evidence that the efficiency of a country's product market affects the value of corporate diversification. Nevertheless, the results of Table III provide strong evidence that different institutional factors do influence the value of corporate diversification. A question that still remains unanswered is whether these results are robust to self-selection models that account for the fact that diversification is not pursued randomly (Villalonga, 2004). 


\section{B. Heckman Selection Models}

In order to account for the selection of firms into diversified status, we investigate the relationship between institutional factors and the excess value of diversified firms using the Heckman two-step selection model (Heckman 1979). In this approach, we model the selection of diversified status in the first stage and model excess values for diversified firms in the second stage. We do so by implementing the Heckman selection model using a maximum likelihood estimator, which estimates the two stages simultaneously. Heckman's approach requires the application of exclusion restrictions to at least one variable - which is included in the first-stage selection model but that can be excluded from the second-stage regression model for the selected firms, since it is uncorrelated with the outcome. To this end, we use a variable used in prior work on the diversification discount: an indicator for whether the firm reports a non-zero amount for the minority interest on its balance sheet (Dimitrov and Tice, 2006; Hund et al., 2010). The rationale for using a minority interest indicator as an instrument is that it proxies for (possibly diversifying) acquisitions that happened in the past but need not be correlated with contemporaneous segment-level unobservables.

[Table IV approximately here]

Table IV displays the results of the Heckman selection models. Similar to the previous table, we have separate selection models for each institutional variable (Models (1) - (3)), and a model with all three institutional variables included at the same time (Model (4)). However, due to the importance of accounting for other institutional factors in the analysis of any one of them, 
we will focus our discussion of this table on the results of the Model (4). Moreover, in the interest of conserving space, we display just the selection-corrected results of the second stage of the Heckman model for Models (1) - (3), but display both stages for the results of our complete model, Model (4). The first-stage results are similar across all four models, though.

The first stage of the model is estimated with 129,667 observations, 35,886 of them representing diversified firms and the rest single-segment firms. Examining the first stage of the Heckman selection model, we observe that our instrumental variable, Minority Interest, has a positive coefficient and is significant at the $1 \%$ level. This is consistent with prior work that has found diversified US firms to be significantly more likely to hold a non-zero amount of minority interest on their balance sheets (Dimitrov and Tice, 2006; Hund et al., 2010). While not the main focus of our empirical analysis, we also note that one of our institutional variables, Labor Market Efficiency, appears to predict the likelihood that a firm would be diversified. Specifically, firms in countries with less efficient labor markets are more likely to be diversified, than in contexts where these markets are more efficient. This would be expected if less-efficient labor markets institutional environments do indeed make diversification more valuable. However, we do not find similar associations between our other institutional variables and the likelihood of diversification. Recent work has found that firms exhibit greater levels of vertical integration in contexts with greater contracting hazards and financial development (Acemoglu, Johnson, and Mitton 2009). Our finding that certain characteristics of the institutional environment also significantly influence the likelihood of corporate diversification (i.e. the horizontal scope of the firm) further extends this literature. 
Turning to the second stage of the Heckman model, we observe that Capital Market Efficiency and Labor Market Efficiency both have negative coefficients that are significant at the 1\% level. Therefore, consistent with our OLS results from Table IV, we continue to find that the value of diversified firms relative to their single-segment counterparts is greater in institutional settings with frictions in their capital and labor markets. Furthermore, in line with the prior OLS

analysis, we again find that Product Market Efficiency has an insignificant effect on the value of diversified firms, after accounting for the other institutional factors. Overall, the results of the Heckman selection models in Table IV provide strong evidence that our earlier findings are not driven by self-selection biases.

\section{Propensity Score Matching}

Villalonga (2004) argues that the diversification discount can be attributed to the difficulty of finding truly comparable single-segment firms. Using propensity-score matching to find comparable firms, she finds that excess values increase on average, to thr point of turning the average discount found in U.S. data into a premium. It is important to recognize that systematically underestimating the value of diversification is not necessarily a problem for this study, because we are interested in the cross-country variation of the discount rather than the average discount. However, if the bias on the value of diversification introduced by the difficulty of finding appropriate comparable firms varies systematically with institutional factors, then this could bias the estimated coefficients on the institutional factors. In other words, if we are 
underestimating the value of diversification more in countries with more developed capital and labor markets then this methodological problem could produce our results.

To examine this alternative explanation, we estimate propensity score matching models and derive an adjusted excess value estimate for each country. These bias-corrected excess values are computed using one-to-one nearest neighbor propensity score matching with a caliper of 0.001, where diversified firms are matched to single-segment firms in the same country on the natural logarithm of total assets, return on assets, cash over assets, capital expenditures over assets, leverage, and dividends paid as a percentage of equity. Due to data limitations, we are only able to derive the estimates for 29 out of 38 countries. Consistent with prior literature, we find that the adjusted excess values are higher for 23 out of the 29 countries. The average mean excess value across countries is $-12.3 \%$ while the adjusted one is $-6.4 \%$. However, the underestimation of excess value did not vary much across countries. Because propensity score matching factors in firm-level variables such as size, profitability, leverage, etc. in the estimation of the discount, we calculated the difference between these propensity score matching estimates and the OLS estimates of the discount (Berger and Ofek 1995). The correlation between this difference and our institutional variables was insignificant.

The univariate correlation between the excess value and the adjusted excess value across countries is 0.95 . In summary, the relations documented here between value of diversification and institutions do not seem to be affected by the selection of comparable firms. 


\section{Robustness Checks}

\section{A. OLS and Heckman Models without Diversified Firms from the United States}

While our sample has a significant number of observations from countries other than the United States, observations from the United States still account for approximately $45 \%$ of our sample. As a result, it is unclear whether our results are driven by the inclusion of these US firms, or whether our institutional variables still explain variation in the value of diversification across a non-US subsample. In the following analysis, we exclude all US firms and model excess values as a function of our institutional factors using both multivariate OLS and Heckman selection models. The results of this analysis on the non-US subsample are presented in Table V.

\section{[Table V approximately here]}

Excluding US firms reduces the sample of diversified firms to 19,799 observations. The results of Table $\mathrm{V}$ are very similar to the results from the prior analyses that included diversified firms from the United States (Tables 3 and 4). As before, we see that Capital Market Efficiency and Labor Market Efficiency have negative coefficients that are significant in both the OLS (at the $5 \%$ level) and Heckman models (at the 1\% level). As a result, we find that the efficiency of capital and labor markets continue to significantly affect the value of diversification across countries outside the United States. Again, the relative value of diversified firms is greater in countries with less efficient capital and labor markets. These results increase our confidence that the results are not driven solely by the inclusion of US firms. 


\section{B. OLS and Heckman Models with Diversified Firms from Countries with at Least 100}

\section{Observations}

Just like there may have been a concern that our results are driven by the large number of observations from the United States, another source of concern may lie in the few observations many countries in our sample have. As an additional robustness test, we exclude all countries from our analysis that have less than 100 diversified-year observations. After enforcing this limit, we are left with only 18 counties, and thus clusters with which to adjust our standard errors. Nevertheless, we present the results of both the OLS analysis and the Heckman selection model run on observations from these 18 countries in Table VI.

[Table VI approximately here]

The results of Table VI are consistent with the results of the main analysis with observations from 38 countries (Table III). Again, we find that Capital Market Efficiency and Labor Market Efficiency have negative coefficients that are significant in both the OLS (at the 5\% level and 1\% level, respectively) and Heckman models (at the 1\% level). As a result, we find that the efficiency of capital and labor markets continue to significantly affect the value of diversification across countries with a larger number of observations in our overall sample. Furthermore, if we were to additionally exclude diversified firms from the United States from the analyses in Table VI, we continue to obtain similar results. The results of this table indicate that our main results are not substantially influenced by the inclusion of countries in our sample with relatively few observations. 


\section{Imputing Segment Value with a Minimum of Three Comparable Firms}

As is standard practice in the literature on the diversification discount, the imputed value of a firm's segment (used to eventually calculate a firm's excess value) was derived from the median market-to-sales ratio of at least five single-segment firms in that industry (Berger and Ofek 1995; Villalonga 2004). However, since the requirement of five single-segments firms in the same industry may be too restrictive for certain countries in our sample, we perform an additional analysis with the requirement of only three comparable single-segment firms needed to impute the value of a firm's segment. The drawback of requiring fewer comparable singlesegment firms is that the imputed value of a firm's segment may potentially be less reliable and noisier than when we require at least five comparable firms. After computing the modified excess values for diversified firms, we analyze the relationship between our institutional variables and these excess values using both a multivariate OLS regression and a Heckman selection model. However, unlike the previous analysis, we only show models where all our institutional variables are included at the same time. The results of this analysis are presented in Table V.

[Table VII approximately here]

The results of Table VII further support the effect of our institutional variables on the value of corporate diversification around the world. The sample now has increased to 42,034 observations from 35,886 observations, where the new observations come primarily from Australia, China, India, Hong Kong, Japan, Canada, the UK, and the United States. In particular, 
after relaxing the requirement of five single-segment comparables to three in order to impute segment values, we continue to find that Capital Market Efficiency and Labor Market Efficiency have negative and significant coefficients (at the $1 \%$ and $10 \%$ levels, respectively) in the OLS model. Turning to the Heckman model, we again find that Capital Market Efficiency is highly significant at the $1 \%$ level. However, in contrast to the OLS results, we find that Labor Market Efficiency is more significant at the 5\% level, after accounting for self-selection. In summary, we continue to find that the relative value of diversified firms is greater in contexts with inefficient capital and labor markets. In the case of Product Market Efficiency, we continue to find that it remains insignificant in influencing the value of diversification across the world. Overall, the results of Table VII are broadly consistent with the significant results of prior analyses that required five single-segment comparables to impute segment values.

\section{Do Within-Country Changes in Institutional Factors Affect the Value of Corporate Diversification?}

While institutional factors have been found to explain cross-sectional variation in the value of diversification across the world, it remains to be seen whether changes in these institutional variables also explain within-country variation in the value of diversification over time. Doing so requires country fixed effects to be included in the multivariate analysis, to isolate the effect of changes in our institutional variables within each country. Prior literature has found that the relative value of diversified firms can change over time. Shleifer and Vishny (1991) and Hubbard and Palia (1999) argue that the reason why conglomerate mergers triggered 
positive market reactions during the 1960s but not during the 1980s is because of the secular increase in the efficiency of external capital markets, which translates into a relative decrease in the perceived efficiency of tha alternative-internal capital markets within conglomerates. Servaes (1996) examines changes in the diversification discount in the United States during the conglomerate merger wave (from 1961 to 1976) and finds that while there was a significant discount in the 1960s, the discount was reduced considerably in the early to late 1970s. Kuppuswamy and Villalonga (2011) show that the value of corporate diversification increased during the global financial crisis of 2008-2009, partly due to changes in the relative efficiency of external and internal capital markets. We extend this line of work with an international sample and examine whether changes in the state of the institutional environment within a country explains changes in the value of diversification. Table VIII displays the results of such an analysis.

[Table VIII approximately here]

Table VIII presents the results of several OLS regression models with each of our institutional variables included separately (Models (1) - (3)), with the final model including all three (Model (4)). Again, each model includes country fixed effects in order to focus on withincountry variation in the value of diversification over time. The results of this table show that Capital Market Efficiency loads significantly in the multivariate analysis (in Models (1) and (4)). However, Labor Market Efficiency does not load significantly both when it is included separately as well as together with the other institutional factors. Moreover, while Product Market 
Efficiency has a positive and marginally significant coefficient in the full model (Model (4)), we view this result with suspicion given its lack of significance when included alone in Model (3). It is more than likely that the marginal significance of Product Market Efficiency in the full model is due to multicollinearity - significantly high variance inflation factors computed for this model support this argument. While we find no evidence that product and labor market efficiency explain within-country variation in the value of corporate diversification, these results should be interpreted with caution since these institutional variables do not change significantly within most countries over time. Nevertheless, we find significant evidence that changes in the state of a country's capital markets do significantly affect the relative value of corporate diversification within the country over time. Consistent with Shleifer and Vishny (1991), Hubbard and Palia (1999) and Kuppuswamy and Villalonga (2011), we find that a country's capital markets become more efficient over time, the value of internal capital allocation decreases. As a result, the value of diversified firms relative to their single-segment peers is found to decrease.

\section{Conclusion}

In this paper, we examine whether and which facets of a country's institutional environment explain the variation in the value of corporate diversification around the world. Using data on diversified firms from 38 countries over a 15 year period, we explore the effect of three key institutional variables - capital market efficiency, labor market efficiency, and product market efficiency - on the excess value of diversified firms relative to their single segment peers. 
Using both OLS and self-selection models, we find that capital and labor market efficiency are important drivers of the value of diversification across the world. In doing so, we directly address recent calls to explore the drivers of cross-sectional variance in the diversification discount, rather than its main effect (Stein, 2003). Moreover, these findings validate theoretical work that highlight the importance of other institutional 'voids', such as the state of a country's labor market, in analyzing the relative value of diversification across the world (Khanna and Palepu, 1999, 2010). Finally, we advance the limited literature examining variation in the value of diversification within countries over time (Servaes, 1996, Kuppuswamy and Villalonga, 2011). To our knowledge, the present study represents to first attempt to use an international sample to investigate within-country variation in the value of diversification. In doing so, we show that amongst all the institutional factors we consider, changes in the efficiency of a country's capital markets drive variation in the excess value of diversified firms over time.

We conclude by identifying a potential avenue for future research. Given the evidence in this paper that the value of diversification is contingent on the institutional infrastructure of a country, it would be interesting for future research to explore within the same firm how financing arrangements differ for diversification activities across countries with different institutional characteristics. Gaining a better understanding of this process would help us understand better the role of finance in the growth of corporations across countries. 


\section{References}

Acemoglu, Daron, Simon Johnson, and Todd Mitton, 2009, Determinants of Vertical Integration: Financial Development and Contracting Costs, The Journal of Finance 64, 1251-1290.

Amihud, Yakov, and Baruch Lev, 1981, Risk Reduction as a Managerial Motive for Conglomerate Mergers, The Bell Journal of Economics 12, pp. 605-617.

Asbaugh, Hollis, and Morton Pincus, 2001, Domestic Accounting Standards, International Accounting Standards, and the Predictability of Earnings, Journal of Accounting Research 39, pp. 417-434.

Berger, Philip G., and Eli Ofek, 1995, Diversification's effect on firm value, Journal of Financial Economics 37, 39-65.

Campa, Jose M., and Simi Kedia, 2002, Explaining the Diversification Discount, Journal of Finance 57, 1731-1762.

Dimitrov, Valentin, and Sheri Tice, 2006, Corporate Diversification and Credit Constraints: Real Effects across the Business Cycle, Review of Financial Studies 19, 1465-1498.

Fauver, Larry, Joel Houston and Andy Naranjo, 2003, Capital market development, legal systems and the value of corporate diversification: a cross-country analysis, Journal of Financial and Quantitative Analysis 38, 135-157.

Healy, Paul M., George Serafeim, Suraj Srinivasan, and Gwen Yu, 2011, Market Competition, Government Efficiency, and Profitability around the World. Harvard Business School Working Paper, No. 12-010.

Heckman, James J., 1979, Sample Selection Bias as a Specification Error, Econometrica 47, pp. 153-161.

Hubbard, R. Glenn, and Darius Palia, 1999, A reexamination of the Conglomerate Merger Wave in the 1960s: An internal capital markets view, Journal of Finance 54, 1131-1152.

Hund, John, Donald Monk, and Sheri Tice, 2010, Rational Learning and the Diversification Discount, Journal of Financial Economics.

Jensen, Michael C., 1986, Agency Costs of Free Cash Flow, Corporate Finance, and Takeovers, The American Economic Review 76, pp. 323-329. 
Khanna, Tarun, and Krishna Palepu, 1999, The Right Way to Restructure Conglomerates in Emerging Markets. (cover story), Harvard Business Review 77, 125-134.

Khanna, Tarun, and Krishna Palepu, 2000, Is Group Affiliation Profitable in Emerging Markets? An Analysis of Diversified Indian Business Groups, The Journal of Finance 55, pp. 867891.

Khanna, Tarun, and Krishna G. Palepu, 2010, Winning in emerging markets: a road map for strategy and execution (Harvard Business Press, Boston, Mass.).

Khanna, Tarun, and Jan W. Rivkin, 2001, Estimating the Performance Effects of Business Groups in Emerging Markets, Strategic Management Journal 22, pp. 45-74.

Kuppuswamy, Venkat and Villalonga, Belén, 2011. Does Diversification Create Value in the Presence of External Financing Constraints? Evidence from the 2008-2009 Financial Crisis. Harvard Business School Finance Working Paper No. 1569546.

Kutner, Michael H., Chris Nachtsheim, and John Neter, 2004, Applied linear regression models (McGraw-Hill/Irwin, Boston ;New York).

Lang, Larry H. P., and René M. Stulz, 1994, Tobin's q, corporate diversification, and firm performance, Journal of Political Economy 102, 1248.

Lins, Karl V., and Henri Servaes, 2002, Is Corporate Diversification Beneficial in Emerging Markets? Financial Management 31, pp. 5-31.

Lins, Karl, and Henri Servaes, 1999, International Evidence on the Value of Corporate Diversification, The Journal of Finance 54, 2215-2239.

Penrose, Edith, 1959, The Theory of the Growth of the Firm (Oxford University Press, Oxford).

Rajan, Raghuram, Henri Servaes, and Luigi Zingales, 2000, The Cost of Diversity: The Diversification Discount and Inefficient Investment, The Journal of Finance 55, 35-80.

Scharfstein, David S., and Jeremy C. Stein, 2000, The Dark Side of Internal Capital Markets: Divisional Rent-Seeking and Inefficient Investment, The Journal of Finance 55, 2537-2564.

Servaes, Henri, 1996, The Value of Diversification During the Conglomerate Merger Wave, Journal of Finance 51, 1201-1225.

Shleifer, Andrei, and Robert W. Vishny, 1989, Management entrenchment: The case of manager-specific investments, Journal of Financial Economics 25, 123-139. 
Shleifer, Andrei, and Robert W. Vishny, 1991, Takeovers in the '60s and '80s: Evidence and implications, Strategic Management Journal 12, 51-59.

Stein, Jeremy C., 1997, Internal Capital Markets and the Competition for Corporate Resources, The Journal of Finance 52, 111-133.

Stein, Jeremy C., 2003, Agency, information and corporate investment, in G.M. Constantinides, M. Harris and R. M. Stulz, eds.: (Elsevier).

Tate, Geoffrey, and Liu Yang (2012), The Bright Side of Corporate Diversification: Evidence from Internal Labor Markets, working paper, UCLA.

Thomson Financial, 2003. Worldscope Database. Electronic database, May 2003.

Villalonga, Belén, 2003, Research Roundtable Discussion: The Diversification Discount, SSRN eLibrary.

Villalonga, Belén, 2004a, Does Diversification Cause the Diversification Discount? Financial Management 33, 5-27.

Villalonga, Belén, 2004b, Diversification Discount or Premium? New Evidence from the Business Information Tracking Series,” Journal of Finance 59, 479-506

Williamson, Oliver E., and Alfred D. Chandler, 1975, Markets and hierarchies, analysis and antitrust implications : a study in the economics of internal organization (Free Press, New York). 
Table I

Breakdown of Diversified Firm Observations by Country

The table presents a breakdown of the number of diversified-year observations for each country in our sample. In addition we present the mean and median Excess Value for diversified firms in each country. Excess Value is the natural logarithm of the ratio of a firm's market value to its imputed value. A firm's imputed value is the sum of its segments' imputed values, which are the product of the segment's sales total with the median market-to-sales ratio of at least five single-segment firms in the same industry.

\begin{tabular}{|c|c|c|c|c|}
\hline Country & $\mathbf{N}$ & $\%$ of sample & $\begin{array}{r}\text { Mean Excess } \\
\text { Value } \\
\end{array}$ & Median Excess Value \\
\hline Australia & 511 & 1.42 & -0.418 & -0.500 \\
\hline Belgium & 5 & 0.01 & 0.035 & 0.446 \\
\hline Brazil & 40 & 0.11 & 0.093 & -0.042 \\
\hline Canada & 1,138 & 3.17 & -0.294 & -0.313 \\
\hline Chile & 4 & 0.01 & -0.062 & 0.020 \\
\hline China & 1,548 & 4.31 & -0.091 & -0.112 \\
\hline Czech Republic & 16 & 0.04 & 0.450 & 0.473 \\
\hline Denmark & 29 & 0.08 & -0.328 & -0.323 \\
\hline Finland & 48 & 0.13 & -0.358 & -0.396 \\
\hline France & 965 & 2.69 & -0.085 & -0.093 \\
\hline Germany & 958 & 2.67 & -0.117 & -0.149 \\
\hline Greece & 33 & 0.09 & -0.076 & -0.177 \\
\hline Hong Kong & 655 & 1.83 & -0.375 & -0.465 \\
\hline India & 573 & 1.6 & -0.073 & -0.061 \\
\hline Indonesia & 159 & 0.44 & 0.063 & 0.164 \\
\hline Ireland & 10 & 0.03 & -0.590 & -0.565 \\
\hline Israel & 60 & 0.17 & -0.014 & -0.072 \\
\hline Italy & 10 & 0.03 & -0.513 & -0.557 \\
\hline Japan & 6,493 & 18.09 & -0.154 & -0.146 \\
\hline South Korea & 90 & 0.25 & -0.079 & -0.104 \\
\hline Malaysia & 363 & 1.01 & -0.269 & -0.279 \\
\hline Mexico & 14 & 0.04 & 0.303 & 0.185 \\
\hline Netherlands & 75 & 0.21 & -0.456 & -0.638 \\
\hline New Zealand & 1 & 0.00 & -0.750 & -0.750 \\
\hline Norway & 61 & 0.17 & -0.251 & -0.331 \\
\hline Philippines & 14 & 0.04 & 0.320 & 0.334 \\
\hline Poland & 21 & 0.06 & 0.300 & 0.423 \\
\hline Russian Federation & 11 & 0.03 & 0.617 & 0.860 \\
\hline Singapore & 384 & 1.07 & -0.235 & -0.203 \\
\hline South Africa & 103 & 0.29 & -0.207 & -0.209 \\
\hline Spain & 6 & 0.02 & -0.680 & -0.583 \\
\hline Sweden & 336 & 0.94 & -0.300 & -0.295 \\
\hline Switzerland & 152 & 0.42 & -0.325 & -0.291 \\
\hline Taiwan & 519 & 1.45 & 0.055 & 0.075 \\
\hline Thailand & 347 & 0.97 & 0.113 & 0.123 \\
\hline Turkey & 12 & 0.03 & 0.545 & 0.554 \\
\hline United Kingdom & 4,035 & 11.24 & -0.217 & -0.220 \\
\hline United States & 16,087 & 44.83 & -0.250 & -0.242 \\
\hline Overall Sample & 35,886 & $100 \%$ & -0.207 & -0.198 \\
\hline
\end{tabular}




\section{Table II}

\section{Summary Statistics and Pairwise Correlations}

The table presents summary statistics and pairwise correlations of variables used in subsequent tables. Excess Value is the natural logarithm of the ratio of a firm's market value to its imputed value. A firm's imputed value is the sum of its segments' imputed values, which are the product of the segment's sales total with the median market-to-sales ratio of at least five single-segment firms in the same industry. Capital Market Efficiency is the logarithm of the reversed ordinal ranking of a country's capital market efficiency derived from the IMD World Competitiveness Yearbook, published annually (rank reversed so that higher values of this measure correspond to countries with greater efficiency). Similarly, Labor Market Efficiency, Product Market Efficiency, and Economic Performance are logarithms of reversed ordinal rankings of a country's labor market efficiency, product market efficiency, and overall economic performance, all extracted from the IMD World Competitiveness Yearbook.

\begin{tabular}{|c|c|c|c|c|c|c|c|c|c|c|c|c|}
\hline & Variable & (1) & (2) & (3) & (4) & (5) & (6) & (7) & (8) & (9) & (10) & (11) \\
\hline$(1)$ & Excess Value & 1.00 & & & & & & & & & & \\
\hline$(2)$ & Capital Market Efficiency & -0.09 & 1.00 & & & & & & & & & \\
\hline (3) & Labor Market Efficiency & -0.06 & 0.36 & 1.00 & & & & & & & & \\
\hline$(4)$ & Product Market Efficiency & -0.07 & 0.68 & 0.49 & 1.00 & & & & & & & \\
\hline (5) & Economic Performance & -0.04 & 0.48 & 0.42 & 0.41 & 1.00 & & & & & & \\
\hline (6) & Log Assets & 0.13 & 0.03 & 0.03 & -0.02 & 0.04 & 1.00 & & & & & \\
\hline (7) & \% Cash of Assets & 0.12 & -0.04 & -0.01 & 0.01 & -0.02 & -0.23 & 1.00 & & & & \\
\hline$(8)$ & Leverage & -0.05 & 0.05 & -0.05 & -0.02 & 0.04 & 0.15 & -0.42 & 1.00 & & & \\
\hline (9) & Dividends as \% of Equity & 0.03 & 0.05 & 0.00 & -0.01 & -0.01 & 0.17 & -0.07 & 0.10 & 1.00 & & \\
\hline (10) & Profitability (ROA) & 0.01 & -0.11 & -0.07 & -0.09 & -0.08 & 0.33 & -0.11 & -0.19 & 0.14 & 1.00 & \\
\hline (11) & \% CAPX of Assets & 0.05 & 0.05 & 0.05 & 0.03 & 0.08 & 0.04 & -0.14 & 0.01 & 0.03 & 0.02 & 1.00 \\
\hline & Mean & -0.207 & 3.786 & 3.750 & 3.602 & 3.868 & 12.260 & 0.153 & 0.524 & 0.029 & -0.018 & 0.054 \\
\hline & Median & -0.198 & 3.970 & 3.892 & 3.584 & 3.989 & 12.143 & 0.096 & 0.529 & 0.006 & 0.027 & 0.038 \\
\hline & St. Dev & 0.650 & 0.368 & 0.372 & 0.205 & 0.257 & 1.997 & 0.169 & 0.225 & 0.076 & 0.202 & 0.061 \\
\hline & Q1 & -0.627 & 3.689 & 3.689 & 3.466 & 3.784 & 10.953 & 0.030 & 0.361 & 0.000 & -0.015 & 0.017 \\
\hline & Q3 & 0.223 & 4.025 & 3.951 & 3.784 & 4.025 & 13.538 & 0.212 & 0.676 & 0.031 & 0.065 & 0.069 \\
\hline
\end{tabular}




\section{Table III}

The Effect of Institutional Factors on the Value of Diversification: OLS Regressions

The table presents multivariate OLS regressions where excess value is modeled as function of three institutional variables - capital market efficiency, labor market efficiency, and product market efficiency. Models (1) - (3) each include only one of these institutional variables, while all three covariates are included together in Model (4). Excess Value is the natural logarithm of the ratio of a firm's market value to its imputed value. A firm's imputed value is the sum of its segments' imputed values, which are the product of the segment's sales total with the median market-to-sales ratio of at least five single-segment firms in the same industry. Capital Market Efficiency is the logarithm of the reversed ordinal ranking of a country's capital market efficiency derived from the IMD World Competitiveness Yearbook, published annually (rank reversed so that higher values of this measure correspond to countries with greater efficiency). Similarly, Labor Market Efficiency, Product Market Efficiency, and Economic Performance are logarithms of reversed ordinal rankings of a country's labor market efficiency, product market efficiency, and overall economic performance, all extracted from the IMD World Competitiveness Yearbook. Standard errors are clustered by country and are in parentheses. Significance levels are denoted by * (10\% level), ** (5\% level), and *** (1\% level).

\begin{tabular}{|c|c|c|c|c|c|c|c|c|}
\hline \multirow[b]{2}{*}{ Capital Market Efficiency } & \multicolumn{2}{|c|}{$\begin{array}{c}(1) \\
\text { Excess Value }\end{array}$} & \multicolumn{2}{|c|}{$\begin{array}{c}(2) \\
\text { Excess Value } \\
\end{array}$} & \multicolumn{2}{|c|}{$\begin{array}{c}\text { (3) } \\
\text { Excess Value }\end{array}$} & \multicolumn{2}{|c|}{$\begin{array}{c}(4) \\
\text { Excess Value }\end{array}$} \\
\hline & $\begin{array}{r}-0.195 \\
(0.046)\end{array}$ & $* * *$ & & & & & $\begin{array}{r}-0.154 \\
(0.053)\end{array}$ & $* * *$ \\
\hline Labor Market Efficiency & & & $\begin{array}{r}-0.124 \\
(0.034)\end{array}$ & $* * *$ & & & $\begin{array}{r}-0.0830 \\
(0.027)\end{array}$ & $* * *$ \\
\hline Product Market Efficiency & & & & & $\begin{array}{r}-0.319 \\
(0.058)\end{array}$ & $* * *$ & $\begin{array}{r}-0.0647 \\
(0.086)\end{array}$ & \\
\hline Economic Performance & $\begin{array}{l}-0.061 \\
(0.057)\end{array}$ & & $\begin{array}{r}-0.107 \\
(0.0602)\end{array}$ & $*$ & $\begin{array}{r}-0.081 \\
(0.052)\end{array}$ & & $\begin{array}{r}-0.0170 \\
(0.057)\end{array}$ & \\
\hline Log Assets & $\begin{array}{r}0.060 \\
(0.012)\end{array}$ & $* * *$ & $\begin{array}{r}0.060 \\
(0.012)\end{array}$ & $* * *$ & $\begin{array}{r}0.0596 \\
(0.012)\end{array}$ & $* * *$ & $\begin{array}{r}0.0605 \\
(0.012)\end{array}$ & $* * *$ \\
\hline Cash Percentage & $\begin{array}{r}0.605 \\
(0.062)\end{array}$ & $* * *$ & $\begin{array}{r}0.608 \\
(0.055)\end{array}$ & $* * *$ & $\begin{array}{r}0.615 \\
(0.056)\end{array}$ & $* * *$ & $\begin{array}{r}0.600 \\
(0.059)\end{array}$ & $* * *$ \\
\hline Leverage & $\begin{array}{r}-0.065 \\
(0.021)\end{array}$ & $* * *$ & $\begin{array}{r}-0.080 \\
(0.026)\end{array}$ & $* * *$ & $\begin{array}{r}-0.075 \\
(0.025)\end{array}$ & $* * *$ & $\begin{array}{r}-0.081 \\
(0.027)\end{array}$ & $* * *$ \\
\hline Dividends & $\begin{array}{r}0.167 \\
(0.165)\end{array}$ & & $\begin{array}{r}0.115 \\
(0.172)\end{array}$ & & $\begin{array}{r}0.115 \\
(0.190)\end{array}$ & & $\begin{array}{r}0.162 \\
(0.162)\end{array}$ & \\
\hline ROA & $\begin{array}{r}-0.200 \\
(0.044)\end{array}$ & $* * *$ & $\begin{array}{r}-0.183 \\
(0.051)\end{array}$ & $* * *$ & $\begin{array}{r}-0.191 \\
(0.0445)\end{array}$ & $* * *$ & $\begin{array}{r}-0.209 \\
(0.042)\end{array}$ & $* * *$ \\
\hline CAPX & $\begin{array}{r}0.688 \\
(0.104)\end{array}$ & $* * *$ & $\begin{array}{r}0.713 \\
(0.092)\end{array}$ & $* * *$ & $\begin{array}{r}0.703 \\
(0.093)\end{array}$ & $* * *$ & $\begin{array}{r}0.695 \\
(0.101)\end{array}$ & $* * *$ \\
\hline Year Fixed Effects & Yes & & Yes & & Yes & & Yes & \\
\hline Constant & $\begin{array}{l}0.0363 \\
(0.162)\end{array}$ & & $\begin{array}{r}-0.0716 \\
(0.194)\end{array}$ & & $\begin{array}{r}0.527 \\
(0.198)\end{array}$ & $* *$ & $\begin{array}{r}0.260 \\
(0.270)\end{array}$ & \\
\hline $\mathrm{N}$ & 35,886 & & 35,886 & & 35,886 & & 35,886 & \\
\hline $\begin{array}{l}\text { Number of Clusters } \\
\text { (Countries) }\end{array}$ & 38 & & 38 & & 38 & & 38 & \\
\hline Adjusted R-Sq & 0.064 & & 0.059 & & 0.062 & & 0.066 & \\
\hline
\end{tabular}




\section{Table IV}

The Effect of Institutional Factors on the Value of Diversification: Heckman Selection Models

The table presents the results of Heckman self-selection models where diversified status is modeled as a probit in the first stage, and where the excess value for diversified firms is modeled in the second stage. The first stage probit requires a sample of both single-segment $(\mathrm{N}=93781)$ and diversified firms $(\mathrm{N}=$ 35886), while the diversified firms represent the selected group for the second stage analysis. Heckman's approach requires the application of exclusion restrictions to at least one variable - which is included in the first-stage selection model but that can be excluded from the second-stage regression model for the selected firms, since it is uncorrelated with the outcome. To this end, we use an indicator, Minority Interest, for whether the firm reports a non-zero amount for the minority interest on its balance sheet. The key independent variables in these selection models are three institutional variables - capital market efficiency, labor market efficiency, and product market efficiency. Models (1) - (4) each include only one of these institutional variables, while all three covariates are included together in Model (4). Furthermore, only the second stages of the Heckman models are shown for Models (1) - (3), while both stages are shown for Model (4). Excess Value is the natural logarithm of the ratio of a firm's market value to its imputed value. A firm's imputed value is the sum of its segments' imputed values, which are the product of the segment's sales total with the median market-to-sales ratio of at least five single-segment firms in the same industry. Capital Market Efficiency is the logarithm of the reversed ordinal ranking of a country's capital market efficiency derived from the IMD World Competitiveness Yearbook, published annually (rank reversed so that higher values of this measure correspond to countries with greater efficiency). Similarly, Labor Market Efficiency, Product Market Efficiency, and Economic Performance are logarithms of reversed ordinal rankings of a country's labor market efficiency, product market efficiency, and overall economic performance, all extracted from the IMD World Competitiveness Yearbook. Standard errors are clustered by country and are in parentheses. Significance levels are denoted by * (10\% level), ** (5\% level), and *** (1\% level).

\begin{tabular}{|c|c|c|c|c|c|c|c|c|c|c|}
\hline \multirow[b]{3}{*}{$\begin{array}{l}\text { Capital Market } \\
\text { Efficiency }\end{array}$} & \multirow{2}{*}{\multicolumn{2}{|c|}{$\begin{array}{c}\text { (1) } \\
\text { Excess Value } \\
\text { (2nd Stage) }\end{array}$}} & \multirow{2}{*}{\multicolumn{2}{|c|}{$\begin{array}{c}\text { (2) } \\
\text { Excess Value } \\
\text { (2nd Stage) }\end{array}$}} & \multirow{2}{*}{\multicolumn{2}{|c|}{$\begin{array}{c}\text { (3) } \\
\text { Excess Value } \\
\text { (2nd Stage) }\end{array}$}} & \multicolumn{4}{|c|}{ (4) } \\
\hline & & & & & & & \multicolumn{2}{|c|}{$\begin{array}{l}\text { Diversified } \\
\text { (1st Stage) }\end{array}$} & \multicolumn{2}{|c|}{$\begin{array}{l}\text { Excess Value } \\
\text { (2nd Stage) }\end{array}$} \\
\hline & $\begin{array}{l}-0.221 \\
(0.042)\end{array}$ & $* * *$ & & & & & $\begin{array}{r}-0.315 \\
(0.237)\end{array}$ & & $\begin{array}{r}-0.182 \\
(0.045)\end{array}$ & $* * *$ \\
\hline $\begin{array}{l}\text { Labor Market } \\
\text { Efficiency }\end{array}$ & & & $\begin{array}{r}-0.135 \\
(0.037)\end{array}$ & $* * *$ & & & $\begin{array}{l}-0.275 \\
(0.118)\end{array}$ & $* *$ & $\begin{array}{r}-0.103 \\
(0.029)\end{array}$ & $* * *$ \\
\hline $\begin{array}{l}\text { Product Market } \\
\text { Efficiency }\end{array}$ & & & & & $\begin{array}{r}-0.343 \\
(0.057)\end{array}$ & $* * *$ & $\begin{array}{r}0.129 \\
(0.278)\end{array}$ & & $\begin{array}{r}-0.0547 \\
(0.079)\end{array}$ & \\
\hline $\begin{array}{l}\text { Economic } \\
\text { Performance }\end{array}$ & $\begin{array}{r}-0.0471 \\
(0.053)\end{array}$ & & $\begin{array}{l}-0.103 \\
(0.060)\end{array}$ & * & $\begin{array}{r}-0.0753 \\
(0.053)\end{array}$ & & $\begin{array}{r}0.324 \\
(0.227)\end{array}$ & & $\begin{array}{r}0.00588 \\
(0.054)\end{array}$ & \\
\hline Log Assets & $\begin{array}{l}0.0681 \\
(0.009)\end{array}$ & $* * *$ & $\begin{array}{r}0.065 \\
(0.011)\end{array}$ & $* * *$ & $\begin{array}{r}0.0653 \\
(0.010)\end{array}$ & $* * *$ & $\begin{array}{r}0.114 \\
(0.014)\end{array}$ & $* * *$ & $\begin{array}{r}0.0694 \\
(0.009)\end{array}$ & $* * *$ \\
\hline Cash Percentage & $\begin{array}{r}0.591 \\
(0.058)\end{array}$ & $* * *$ & $\begin{array}{r}0.600 \\
(0.050)\end{array}$ & $* * *$ & $\begin{array}{r}0.605 \\
(0.0518)\end{array}$ & $* * *$ & $\begin{array}{l}-0.221 \\
(0.201)\end{array}$ & & $\begin{array}{r}0.584 \\
(0.0535)\end{array}$ & $* * *$ \\
\hline Leverage & $\begin{array}{r}-0.049 \\
(0.017)\end{array}$ & $* * *$ & $\begin{array}{r}-0.072 \\
(0.023)\end{array}$ & $* * *$ & $\begin{array}{r}-0.0640 \\
(0.020)\end{array}$ & $* * *$ & $\begin{array}{r}0.209 \\
(0.106)\end{array}$ & $* *$ & $\begin{array}{r}-0.065 \\
(0.020)\end{array}$ & $* * *$ \\
\hline Dividends & 0.168 & & 0.113 & & 0.112 & & -0.008 & & 0.164 & \\
\hline
\end{tabular}




\begin{tabular}{|c|c|c|c|c|c|c|c|c|c|c|}
\hline & $(0.161)$ & & (0.173) & & $(0.190)$ & & $(0.340)$ & & $(0.156)$ & \\
\hline ROA & $\begin{array}{r}-0.186 \\
(0.049)\end{array}$ & $* * *$ & $\begin{array}{r}-0.175 \\
(0.056)\end{array}$ & $* * *$ & $\begin{array}{r}-0.180 \\
(0.050)\end{array}$ & $* * *$ & $\begin{array}{r}0.192 \\
(0.068)\end{array}$ & $* * *$ & $\begin{array}{r}-0.195 \\
(0.046)\end{array}$ & $* * *$ \\
\hline CAPX & $\begin{array}{r}0.573 \\
(0.097)\end{array}$ & $* * *$ & $\begin{array}{r}0.651 \\
(0.107)\end{array}$ & $* * *$ & $\begin{array}{r}0.623 \\
(0.084)\end{array}$ & $* * *$ & $\begin{array}{l}-1.717 \\
(0.566)\end{array}$ & $* * *$ & $\begin{array}{r}0.572 \\
(0.093)\end{array}$ & $* * *$ \\
\hline $\begin{array}{l}\text { Minority } \\
\text { Interest }\end{array}$ & & & & & & & $\begin{array}{r}0.282 \\
(0.049)\end{array}$ & $* * *$ & & \\
\hline $\begin{array}{l}\text { Year Fixed } \\
\text { Effects }\end{array}$ & Yes & & Yes & & Yes & & Yes & & Yes & \\
\hline Constant & $\begin{array}{r}-0.104 \\
(0.122)\end{array}$ & & $\begin{array}{r}-0.148 \\
(0.181)\end{array}$ & & $\begin{array}{r}0.464 \\
(0.168)\end{array}$ & $* * *$ & $\begin{array}{r}-1.179 \\
(1.344)\end{array}$ & & $\begin{array}{r}0.120 \\
(0.206)\end{array}$ & \\
\hline Rho & 0.14 & $* *$ & 0.08 & & 0.10 & $*$ & & & 0.15 & $* * *$ \\
\hline $\mathrm{N}$ & 35,886 & & 35,886 & & 35,886 & & 129,667 & & 35,886 & \\
\hline $\begin{array}{l}\text { Number of } \\
\text { Clusters } \\
\text { (Countries) }\end{array}$ & 38 & & 38 & & 38 & & & & 38 & \\
\hline
\end{tabular}




\section{Table V}

\section{The Effect of Institutional Factors on the Value of Diversification:}

\section{Excluding Diversified Firms from the USA}

The table presents the results of both OLS and Heckman self-selection models of excess value where firms from the United States are excluded from the sample. In the Heckman model, diversified status is modeled as a probit in the first stage, and where the excess value for diversified firms is modeled in the second stage. The first stage probit requires a sample of both single-segment and diversified firms, while the diversified firms represent the selected group for the second stage analysis. Heckman's approach requires the application of exclusion restrictions to at least one variable - which is included in the firststage selection model but that can be excluded from the second-stage regression model for the selected firms, since it is uncorrelated with the outcome. To this end, we use an indicator, Minority Interest, for whether the firm reports a non-zero amount for the minority interest on its balance sheet. The key independent variables in both the OLS and selection models are three institutional variables - capital market efficiency, labor market efficiency, and product market efficiency. Excess Value is the natural logarithm of the ratio of a firm's market value to its imputed value. A firm's imputed value is the sum of its segments' imputed values, which are the product of the segment's sales total with the median marketto-sales ratio of at least five single-segment firms in the same industry. Capital Market Efficiency is the logarithm of the reversed ordinal ranking of a country's capital market efficiency derived from the IMD World Competitiveness Yearbook, published annually (rank reversed so that higher values of this measure correspond to countries with greater efficiency). Similarly, Labor Market Efficiency, Product Market Efficiency, and Economic Performance are logarithms of reversed ordinal rankings of a country's labor market efficiency, product market efficiency, and overall economic performance, all extracted from the IMD World Competitiveness Yearbook. Standard errors are clustered by country and are in parentheses. Significance levels are denoted by * (10\% level), ** (5\% level), and *** (1\% level).

\begin{tabular}{|c|c|c|c|c|c|c|}
\hline \multirow[b]{3}{*}{ Capital Market Efficiency } & \multicolumn{2}{|c|}{ OLS } & \multicolumn{4}{|c|}{ Heckman Selection Model } \\
\hline & \multicolumn{2}{|c|}{ Excess Value } & \multicolumn{2}{|c|}{$\begin{array}{l}\text { Diversified } \\
\text { (1st Stage) }\end{array}$} & \multicolumn{2}{|c|}{$\begin{array}{c}\text { Excess Value } \\
\text { (2nd Stage) }\end{array}$} \\
\hline & $\begin{array}{r}-0.111 \\
(0.053)\end{array}$ & $* *$ & $\begin{array}{l}-0.245 \\
(0.229)\end{array}$ & & $\begin{array}{r}-0.142 \\
(0.0455)\end{array}$ & $* * *$ \\
\hline Labor Market Efficiency & $\begin{array}{r}-0.065 \\
(0.028)\end{array}$ & $* *$ & $\begin{array}{r}-0.214 \\
(0.114)\end{array}$ & * & $\begin{array}{r}-0.086 \\
(0.031)\end{array}$ & $* * *$ \\
\hline Product Market Efficiency & $\begin{array}{r}-0.146 \\
(0.092)\end{array}$ & & $\begin{array}{r}0.205 \\
(0.294)\end{array}$ & & $\begin{array}{r}-0.118 \\
(0.081)\end{array}$ & \\
\hline Economic Performance & $\begin{array}{r}0.001 \\
(0.050)\end{array}$ & & $\begin{array}{r}0.448 \\
(0.168)\end{array}$ & $* * *$ & $\begin{array}{r}0.048 \\
(0.048)\end{array}$ & \\
\hline Minority Interest & & & $\begin{array}{r}0.283 \\
(0.067)\end{array}$ & $* * *$ & & \\
\hline Controls & Yes & & Yes & & Yes & \\
\hline Year Fixed Effects & Yes & & Yes & & Yes & \\
\hline Constant & $\begin{array}{r}0.580 \\
(0.260)\end{array}$ & $* *$ & $\begin{array}{r}-2.771 \\
(1.023)\end{array}$ & $* * *$ & $\begin{array}{r}0.190 \\
(0.249)\end{array}$ & \\
\hline $\mathrm{N}$ & 19,799 & & 66,078 & & 19,799 & \\
\hline Number of Clusters (Countries) & 37 & & & & 37 & \\
\hline Adjusted R-Sq & 0.048 & & & & & \\
\hline Rho & & & & & 0.211 & $* * *$ \\
\hline
\end{tabular}




\section{Table VI}

The Effect of Institutional Factors on the Value of Diversification: Excluding Diversified Firms from Countries with less than 100 Observations

The table presents the results of both OLS and Heckman self-selection models of excess value where firms from countries with less than 100 observations are excluded from the sample. In the Heckman model, diversified status is modeled as a probit in the first stage, and where the excess value for diversified firms is modeled in the second stage. The first stage probit requires a sample of both singlesegment and diversified firms, while the diversified firms represent the selected group for the second stage analysis. Heckman's approach requires the application of exclusion restrictions to at least one variable - which is included in the first-stage selection model but that can be excluded from the secondstage regression model for the selected firms, since it is uncorrelated with the outcome. To this end, we use an indicator, Minority Interest, for whether the firm reports a non-zero amount for the minority interest on its balance sheet. The key independent variables in both the OLS and selection models are three institutional variables - capital market efficiency, labor market efficiency, and product market efficiency. Excess Value is the natural logarithm of the ratio of a firm's market value to its imputed value. A firm's imputed value is the sum of its segments' imputed values, which are the product of the segment's sales total with the median market-to-sales ratio of at least five single-segment firms in the same industry. Capital Market Efficiency is the logarithm of the reversed ordinal ranking of a country's capital market efficiency derived from the IMD World Competitiveness Yearbook, published annually (rank reversed so that higher values of this measure correspond to countries with greater efficiency). Similarly, Labor Market Efficiency, Product Market Efficiency, and Economic Performance are logarithms of reversed ordinal rankings of a country's labor market efficiency, product market efficiency, and overall economic performance, all extracted from the IMD World Competitiveness Yearbook. Standard errors are clustered by country and are in parentheses. Significance levels are denoted by * $(10 \%$ level), ** (5\% level), and *** (1\% level).

\begin{tabular}{|c|c|c|c|c|c|c|}
\hline \multirow[b]{3}{*}{ Capital Market Efficiency } & \multicolumn{2}{|l|}{ OLS } & \multicolumn{4}{|c|}{ Heckman Selection Model } \\
\hline & \multicolumn{2}{|c|}{ Excess Value } & \multicolumn{2}{|c|}{$\begin{array}{l}\text { Diversified } \\
\text { (1st Stage) }\end{array}$} & \multicolumn{2}{|c|}{$\begin{array}{c}\text { Excess Value } \\
\text { (2nd Stage) }\end{array}$} \\
\hline & $\begin{array}{c}-0.153 \\
(0.055)\end{array}$ & $* *$ & $\begin{array}{r}-0.369 \\
(0.273)\end{array}$ & & $\begin{array}{c}-0.182 \\
(0.046)\end{array}$ & $* * *$ \\
\hline Labor Market Efficiency & $\begin{array}{r}-0.093 \\
(0.028)\end{array}$ & $* * *$ & $\begin{array}{r}-0.289 \\
(0.132)\end{array}$ & $* *$ & $\begin{array}{r}-0.112 \\
(0.028)\end{array}$ & $* * *$ \\
\hline Product Market Efficiency & $\begin{array}{r}-0.052 \\
(0.088)\end{array}$ & & $\begin{array}{r}0.212 \\
(0.305)\end{array}$ & & $\begin{array}{l}-0.038 \\
(0.082)\end{array}$ & \\
\hline Economic Performance & $\begin{array}{r}-0.006 \\
(0.066)\end{array}$ & & $\begin{array}{r}0.203 \\
(0.331)\end{array}$ & & $\begin{array}{r}0.007 \\
(0.060)\end{array}$ & \\
\hline Minority Interest & & & $\begin{array}{r}0.271 \\
(0.052)\end{array}$ & $* * *$ & & \\
\hline Controls & Yes & & Yes & & Yes & \\
\hline Year Fixed Effects & Yes & & Yes & & Yes & \\
\hline Constant & $\begin{array}{r}0.201 \\
(0.276)\end{array}$ & & $\begin{array}{r}-0.780 \\
(1.693)\end{array}$ & & $\begin{array}{r}0.098 \\
(0.220)\end{array}$ & \\
\hline $\mathrm{N}$ & 35,326 & & 126,109 & & 35,326 & \\
\hline Number of Clusters (Countries) & 18 & & & & 18 & \\
\hline Adjusted R-Sq & 0.064 & & & & & \\
\hline Rho & & & & & $0.141^{* *}$ & \\
\hline
\end{tabular}




\section{Table VII \\ The Effect of Institutional Factors on the Value of Diversification: Segment Value Imputed using at least Three Single-Segment Comparables}

The table presents the results of both OLS and Heckman self-selection models of excess value, where the imputed value of a segment requires only three comparable single-segment firms (rather than five). In the Heckman model, diversified status is modeled as a probit in the first stage, and where the excess value for diversified firms is modeled in the second stage. The first stage probit requires a sample of both single-segment $(\mathrm{N}=100733)$ and diversified firms $(\mathrm{N}=42034)$, while the diversified firms represent the selected group for the second stage analysis. Heckman's approach requires the application of exclusion restrictions to at least one variable - which is included in the first-stage selection model but that can be excluded from the second-stage regression model for the selected firms, since it is uncorrelated with the outcome. To this end, we use an indicator, Minority Interest, for whether the firm reports a non-zero amount for the minority interest on its balance sheet. The key independent variables in both the OLS and selection models are three institutional variables - capital market efficiency, labor market efficiency, and product market efficiency. Excess Value is the natural logarithm of the ratio of a firm's market value to its imputed value. A firm's imputed value is the sum of its segments' imputed values, which are the product of the segment's sales total with the median market-to-sales ratio of at least three single-segment firms in the same industry. Capital Market Efficiency is the logarithm of the reversed ordinal ranking of a country's capital market efficiency derived from the IMD World Competitiveness Yearbook, published annually (rank reversed so that higher values of this measure correspond to countries with greater efficiency). Similarly, Labor Market Efficiency, Product Market Efficiency, and Economic Performance are logarithms of reversed ordinal rankings of a country's labor market efficiency, product market efficiency, and overall economic performance, all extracted from the IMD World Competitiveness Yearbook. Standard errors are clustered by country and are in parentheses. Significance levels are denoted by * (10\% level), ** (5\% level), and *** (1\% level).

\begin{tabular}{|c|c|c|c|c|c|c|}
\hline \multirow[b]{3}{*}{ Capital Market Efficiency } & \multirow{2}{*}{\multicolumn{2}{|c|}{$\begin{array}{c}\text { OLS } \\
\text { Excess Value }\end{array}$}} & \multicolumn{4}{|c|}{ Heckman Selection Model } \\
\hline & & & \multicolumn{2}{|c|}{$\begin{array}{l}\text { Diversified } \\
\text { (1st Stage) }\end{array}$} & \multicolumn{2}{|c|}{$\begin{array}{l}\text { Excess Value } \\
\text { (2nd Stage) }\end{array}$} \\
\hline & $\begin{array}{l}-0.151 \\
(0.052)\end{array}$ & $* * *$ & $\begin{array}{l}-0.342 \\
(0.227)\end{array}$ & & $\begin{array}{c}-0.174 \\
(0.047)\end{array}$ & $* * *$ \\
\hline Labor Market Efficiency & $\begin{array}{l}-0.052 \\
(0.026)\end{array}$ & $*$ & $\begin{array}{r}-0.260 \\
(0.114)\end{array}$ & $* *$ & $\begin{array}{r}-0.067 \\
(0.029)\end{array}$ & $* *$ \\
\hline Product Market Efficiency & $\begin{array}{l}-0.060 \\
(0.080)\end{array}$ & & $\begin{array}{r}0.101 \\
(0.275)\end{array}$ & & $\begin{array}{r}-0.053 \\
(0.075)\end{array}$ & \\
\hline Economic Performance & $\begin{array}{r}0.005 \\
(0.045)\end{array}$ & & $\begin{array}{r}0.324 \\
(0.163)\end{array}$ & $* *$ & $\begin{array}{r}0.022 \\
(0.045)\end{array}$ & \\
\hline Minority Interest & & & $\begin{array}{r}0.290 \\
(0.0461)\end{array}$ & $* * *$ & & \\
\hline Controls & Yes & & Yes & & Yes & \\
\hline Year Fixed Effects & Yes & & Yes & & Yes & \\
\hline Constant & $\begin{array}{r}0.057 \\
(0.220)\end{array}$ & & $\begin{array}{r}-1.002 \\
(1.161)\end{array}$ & & $\begin{array}{l}-0.046 \\
(0.181)\end{array}$ & \\
\hline $\mathrm{N}$ & 42,034 & & 142,767 & & 42,034 & \\
\hline Number of Clusters (Countries) & 40 & & & & 40 & \\
\hline Adjusted R-Sq & 0.056 & & & & & \\
\hline Rho & & & & & 0.115 & $* * *$ \\
\hline
\end{tabular}


Table VIII

The Effect of Changes in Institutional Factors over Time on the Value of Diversification: A Within-Country Analysis

The table presents the results of a within-country analysis of excess values over time. Using multivariate OLS regressions with country fixed effects, excess value is modeled as function of three institutional variables - capital market efficiency, labor market efficiency, and product market efficiency. Models (1) - (3) each include only one of these institutional variables, while all three covariates are included together in Model (4). Excess Value is the natural logarithm of the ratio of a firm's market value to its imputed value. A firm's imputed value is the sum of its segments' imputed values, which are the product of the segment's sales total with the median market-to-sales ratio of at least five single-segment firms in the same industry. Capital Market Efficiency is the logarithm of the reversed ordinal ranking of a country's capital market efficiency derived from the IMD World Competitiveness Yearbook, published annually (rank reversed so that higher values of this measure correspond to countries with greater efficiency). Similarly, Labor Market Efficiency, Product Market Efficiency, and Economic Performance are logarithms of reversed ordinal rankings of a country's labor market efficiency, product market efficiency, and overall economic performance, all extracted from the IMD World Competitiveness Yearbook. Standard errors are clustered by country and are in parentheses. Significance levels are denoted by * $(10 \%$ level), ** (5\% level), and *** (1\% level).

(1)

(2)

(3)

(4)

\begin{tabular}{|c|c|c|c|c|c|c|c|}
\hline \multirow[b]{2}{*}{ Capital market Efficiency } & \multicolumn{2}{|c|}{ Excess Value } & \multicolumn{2}{|c|}{ Excess Value } & \multirow[t]{2}{*}{ Excess Value } & \multicolumn{2}{|c|}{ Excess Value } \\
\hline & $\begin{array}{r}-0.102 \\
(0.033)\end{array}$ & $* * *$ & & & & $\begin{array}{c}-0.111 \\
(0.049)\end{array}$ & $* *$ \\
\hline Labor Market Efficiency & & & $\begin{array}{r}-0.101 \\
(0.066)\end{array}$ & & & $\begin{array}{r}-0.098 \\
(0.069)\end{array}$ & \\
\hline Product Market Efficiency & & & & & $\begin{array}{r}-0.004 \\
(0.042)\end{array}$ & $\begin{array}{r}0.093 \\
(0.047)\end{array}$ & $*$ \\
\hline Economic Performance & $\begin{array}{r}0.050 \\
(0.040)\end{array}$ & & $\begin{array}{r}0.051 \\
(0.045)\end{array}$ & & $\begin{array}{c}0.0201 \\
(0.043)\end{array}$ & $\begin{array}{r}0.074 \\
(0.043)\end{array}$ & $*$ \\
\hline Controls & Yes & & Yes & & Yes & Yes & \\
\hline Year Fixed Effects & Yes & & Yes & & Yes & Yes & \\
\hline Country Fixed Effects & Yes & & Yes & & Yes & Yes & \\
\hline Constant & $\begin{array}{r}-0.792 \\
(0.143)\end{array}$ & $* * *$ & $\begin{array}{r}-0.819 \\
(0.191)\end{array}$ & $* * *$ & $\begin{array}{c}-1.074 \\
(0.187)\end{array}$ & $\begin{array}{c}-0.801 \\
(0.151)\end{array}$ & $* * *$ \\
\hline $\mathrm{N}$ & 35,886 & & 35,886 & & 35,886 & 35,886 & \\
\hline Number of Clusters (Countries) & 38 & & 38 & & 38 & 38 & \\
\hline Adjusted R-Sq & 0.078 & & 0.078 & & 0.077 & 0.078 & \\
\hline
\end{tabular}




\section{Appendix}

Data Items Used to Construct Institutional Environment Variables

\begin{tabular}{|c|c|}
\hline Data Item & Measure \\
\hline \multicolumn{2}{|l|}{ Capital Market Efficiency } \\
\hline \multicolumn{2}{|l|}{ Bank Efficiency } \\
\hline Banking sector assets & Percentage of GDP \\
\hline Banking and financial services & Banking and financial services do support business activities efficiently \\
\hline Financial institutions' transparency & Financial institutions' transparency is sufficiently implemented \\
\hline Finance and banking regulation & Finance and banking regulation is sufficiently effective \\
\hline Financial risk factor & The risk factor in the financial system is adequately addressed. \\
\hline \multicolumn{2}{|l|}{ Stock Market Efficiency } \\
\hline Stock markets & Stock markets provide adequate financing to companies \\
\hline Stock market capitalization & Percentage of GDP \\
\hline Value traded on stock markets & US\$ per capita \\
\hline Listed domestic companies & Number of listed domestic companies \\
\hline Shareholders' rights & Shareholders' rights are sufficiently implemented \\
\hline \multicolumn{2}{|l|}{ Finance Management } \\
\hline Credit & Credit is easily available for businesses \\
\hline Venture capital & Venture capital is easily available for businesses \\
\hline Corporate debt & Corporate debt does not restrain the ability of enterprises to compete \\
\hline \multicolumn{2}{|l|}{ Labor Market Efficiency } \\
\hline Labor regulations & Labor regulations do not hinder business activities \\
\hline Unemployment legislation & Unemployment legislation provides an incentive to look for work \\
\hline Immigration laws & Immigration laws do not prevent your company from employing foreign labor \\
\hline Redundancy costs & Number of weeks of salary \\
\hline Labor market flexibility & Index on rigidity of employment (index 0-100) \\
\hline \multicolumn{2}{|l|}{ Product Market Efficiency } \\
\hline \multicolumn{2}{|l|}{ Openness } \\
\hline Tariff barriers & Tariffs on imports: Most favored nation simple average rate \\
\hline Customs' authorities & Customs' authorities do facilitate the efficient transit of goods \\
\hline Protectionism & Protectionism does not impair the conduct of your business \\
\hline Public sector contracts & Public sector contracts are sufficiently open to foreign bidders \\
\hline \multicolumn{2}{|l|}{ Competition and Regulations } \\
\hline Government subsidies & To private and public companies as a percentage of GDP \\
\hline Subsidies & Subsidies do not distort fair competition and economic development \\
\hline State ownership of enterprises & State ownership of enterprises is not a threat to business activities \\
\hline Competition legislation & Competition legislation is efficient in preventing unfair competition \\
\hline Parallel economy & Parallel (black-market) economy does not impair economic development \\
\hline Ease of doing business & Ease of doing business is supported by regulations \\
\hline Creation of firms & Creation of firms is supported by legislation \\
\hline Start-up days & Number of days to start a business \\
\hline Start-up procedures & Number of procedures to start a business \\
\hline
\end{tabular}

\section{Source: IMD World Competitiveness Reports}

